\title{
The Enforcement of Contracts and Property Rights: Constitutive versus Epiphenomenal Conceptions of Law
}

\author{
by Geoffrey M. Hodgson
}

25 April 2003

Presented at CRIC Polanyi Conference in Manchester, 23-25 October 2002

Published in the International Review of Sociology, 13(2), 2003, pp. 373-89.

\author{
The Business School, University of Hertfordshire, De Havilland Campus, Hatfield, Hertfordshire AL10 9AB, UK \\ http://www.herts.ac.uk/business/esst/Staff/g-hodgson/hodgson.html \\ http://www.geoffrey-hodgson.ws \\ Address for correspondence: \\ Malting House, 1 Burton End, West Wickham, Cambridgeshire CB1 6SD, UK \\ g.m.hodgson@herts.ac.uk
}

KEY WORDS: Property, markets, the state, law

\author{
JEL classification
}

\begin{abstract}
This paper considers the status of laws and legal institutions in modern socio-economic systems, particularly those laws relating to property, contracts and trade. Are such laws mere reflections of other socio-economic relationships between individuals or social classes, or is law itself a part of the underlying socio-economic reality? Albeit in different ways, both Marxists and individualists (in an analytical sense considered here) have typically favoured the idea that law is an epiphenomenon. In contrast, it is argued in this paper that legal relations are partly constitutive of reality. This argument is extended to support Karl Polanyi's proposition that markets cannot function properly without some intervention by the state.
\end{abstract}




\title{
The Enforcement of Contracts and Property Rights: Constitutive versus Epiphenomenal Conceptions of Law
}

\author{
by Geoffrey M. Hodgson
}

By what means are property rights sustained and contracts enforced? ${ }^{1}$ The purpose of this paper is to consider the role and ontological status of law and legal systems in modern, complex socio-economic systems. Are such laws mere reflections of other socio-economic relationships between individuals or social classes, or is law itself a part of the underlying socio-economic reality? This enquiry raises general questions concerning the relationship between legal and economic institutions, and the relationship between markets and the state in particular.

The first and second sections of this paper address, respectively, Marxism and a doctrine that I broadly describe as 'individualism'. It is argued that Marxism treats law as an expression (or epiphenomenon) of underlying (and inadequately defined) social relations. Individualism treats law as a mere formalisation of spontaneous outcomes of individual interactions. Hence, in different ways, both Marxists and individualists have typically favoured the idea that law is an epiphenomenon.

In contrast, it is argued in the third section that legal relations are partly constitutive of reality. Section four considers some general aspects of institutions, among which legal institutions are included. This prepares the ground for the discussion in section five, of different types of mechanism of institutional emergence and rule enforcement. It is argued that individualists have given too much relative emphasis to spontaneously emerging institutions and many legal institutions are not of this type. Many legal institutions, including contracts and property rights, cannot be generally enforced in a complex society without 'third party' institutional intervention, such as by the state. This argument is extended to support Karl Polanyi's proposition that markets cannot function properly without some state intervention.

\section{Marxism: Law as an Epiphenomenon of Underlying Structures}

An epiphenomenal conception of law is one that regards laws and legal systems as expressions of another more fundamental level of reality, which itself does not include juridical relations. In other words, laws and legal systems are regarded as mere surface phenomena. This view of law is found among a wide variety of thinkers, adopting diverse methodological positions and political stances. This diversity will be manifest in the selection of writers considered below.

\footnotetext{
1 The author thanks the participants at the October 2002 CRIC Workshop in Manchester and others at various seminars who have commented on earlier drafts of this essay, including Jürgen Backhaus, Mark Blaug, Uskali Mäki, Stan Metcalfe and Jack Vromen. This paper makes use of some material from Hodgson (2004).
} 
In the famous Preface to the Contribution to the Critique of Political Economy of 1859, Karl Marx (1971, p. 20) saw legal relations as part of the 'superstructure' built on 'the economic structure':

The totality of these relations of production constitutes the economic structure of society, the real foundation, on which arises a legal and political superstructure and to which correspond definite forms of social consciousness.

Marx (1971, p. 21) saw 'property relations' as 'merely' an expression 'in legal terms' of the 'relations of production' in society. He continued:

it is always necessary to distinguish between the material transformation of the economic conditions of production, which can be determined with the precision of natural science, and the legal, political, religious, artistic or philosophic - in short, ideological forms in which men become conscious of this conflict and fight it out.

Here law for Marx was an 'ideological form' of a relatively superficial character and lower epistemological status than the 'material' and 'economic conditions of production', which allegedly but inexplicably are more subject to scientific dissection. A similar treatment of legal relations is found in the first volume of Capital, which initially appeared in 1867 . There Marx (1976, p. 178) wrote:

The juridical relation, whose form is the contract, whether as part of a developed legal system or not, is a relation between two wills which mirrors the economic relation. The content of this juridical relation (or relation of two wills) is itself determined by the economic relation.

This again suggests that such changes in the legal form of the contract are surface phenomena. The grain of truth in this argument is that legal formalities are never adequate or accurate summaries of economic or social relationships. The flaw in the argument is to fail to recognise that economic content is affected by legal relations, as well as vice versa. Each direction of causality requires us to recognise the reality and importance of the legal form. Accordingly, the legal form of the contract gives use clues about the underlying economic relation, even if the mirror to which Marx alludes is always in fact a distorting one.

What is striking in Marx's diverse writings on this question is his failure to define adequately key terms such as 'economic structure', 'relations of production', 'economic conditions of production', or 'economic relations'. The meaning of these terms is not selfevident and they cry out for definition. Furthermore, a clear meaning has to be given to these terms to give meaning to Marx's strict dichotomy between 'economic' and 'legal' relations. His failure to define the 'economic' deprives his argument of analytical force.

Lack of clarity is not confined to Marxism. In the literature in the social sciences as a whole, the term 'economic' carries a multiplicity of meanings. Meanings range from connotations of 'material production' to being concerned with 'economy' in a sense of costreduction or efficiency. Marx hinted at the first meaning, but few economists today would see the economy as essentially the sphere of material production. 'Economics' is regarded by mainstream economists as the study of choice under conditions of scarcity, wherever they may apply. I am not defending this definition here. I am simply pointing out that no consensus exists over the meaning of terms such as 'economy', 'economic' or 'economic relation'. This consensus has been lacking during the nineteenth and the twentieth centuries. Neither is there a commonly accepted definition of the term 'relations of production'. Hence, when we find these terms in the writings of Marx or anyone else we cannot take them as self-evident. 
Whatever, 'the economy' might mean, for Marx its essential structures do not include legal relations. The law is seen as an expression or reflection of these 'economic relations' or 'relations of production'. What Marx rules out is the possibility that laws may be a necessary and essential part of these 'economic relations' or 'relations of production'. Certainly, for Marx and subsequent Marxists, the presumption has often been that changes in fundamental 'economic relations' or 'relations of production' would of themselves lead to more superficial or confirmatory changes in the law. The danger here is that the importance of law is itself downgraded, in both analytical and policy terms.

At root here are questions of social ontology. Marx and Engels (1976, p. 59) wrote in the German Ideology in about 1845-47: 'ruling ideas are nothing more than the ideal expressions of the dominant material relations'. Again, the meaning of 'material relations' is never defined, but it is clear that Marx and Engels regard them as fundamental, while law is epiphenomenal and in the secondary realm of ideas and ideologies. In emphasising matter over ideas, Marx and Engels were clearly reacting against German idealism, but in doing so they developed formulations that were extreme in some respects and ill-defined in others.

Within their social ontology, legal relations are secondary to an unelaborated 'material' essence. The closest that Marx and Engels (1976, pp. 41-2) get to a clarification and justification of this 'materialist' position is their statement that

men must be in a position to live in order to be able to 'make history'. But life involves before everything else eating and drinking, housing, clothing and various other things. The first historical act is thus the production of the means to satisfy these needs, the production of material life itself.

There is an important element of truth here. Basic human needs, such as food and shelter, must be satisfied to make human life possible. However, as Marx and Engels themselves emphasised, production and consumption are social processes, involving social structures and relations between individuals. Social relations and institutions are just as necessary for human society as production itself.

Even in early and primitive human societies, social relations, including those linked to the production of human needs, involved social rules. Some of these rules could be described as laws. Hence it does not follow from the above argument by Marx and Engels that social rules and legal relations necessarily have a secondary status. The production of human needs involves social relations, social rules and ideas, as well as material objects. On this basis there is no convincing argument to give the latter priority or ontological primacy.

\section{Individualism: Law as an Epiphenomenon of Individual Interactions}

Marxism differs substantially from both ontological and methodological individualism (Heijdra et al. 1988; Sensat, 1988). Ontological individualism upholds that social reality consists of nothing else but individuals. Methodological individualism is the idea that all social phenomena should be explained only in terms of individuals, individual preferences or individual goals. In the case of ontological individualism, law has no status other than an attribute of individuals, including their attitudes or beliefs. In other cases of methodological individualism it would be possible to see law as epiphenomenal to relations or interactions between individuals, but explicable completely in the terms of the individuals themselves. 
Without going into further details, we may bear these nuances in mind when considering the broad type of approach that I shall describe in general terms as 'individualist'. The following examples should help to clarify what I mean by this term in this context.

Robert Sugden (1986, p. 5) spoke for many sharing his individualist preconceptions when he argued that legal codes 'merely formalize ... conventions of behaviour' that have evolved spontaneously out of individual interactions. Others downgrade the reality of legal structures in the manner in which they define such concepts as property and exchange. Ludwig von Mises (1949) and others have defined production as an 'exchange with nature' thus downgrading the concept of exchange by ignoring the fact that nature itself cannot own or enforce property rights. Armen Alchian (1977, p. 238) defined the property rights of a person in the universal terms of 'the probability that his decision about demarcated uses of the resource will determine the use'. The upshot of this definition is that if a thief manages to keep stolen goods then he acquires a substantial property right in them, even if, on the contrary, legal or moral conclusions would suggest that they remain the rightful property of their original owner.

The individualist approach to the understanding of legal relations is generally exemplified in the work of some 'new institutional economists' who attempt to explain all institutions including legal institutions - in terms of individuals and their interactions. ${ }^{2}$ This methodological individualism is applied to legal institutions such as property and the state. For example, Richard Posner (1980) developed a theory of the emergence of property in primitive societies that depended on elaborate 'insurance' arrangements between parties.

In terms similar to Posner, Oliver Williamson (1983) wrote of a system of 'hostages', where both parties to an agreement are committed to non-salvageable costs. This argument suggests that a system of contract is possible and sustainable without the intervention of a legal system. The morsel of truth here is that it is sometimes more costly for parties to break a contract than to complete it. Accordingly, there can be strong incentives for contract compliance other than legal sanctions alone. Nevertheless, the 'hostages' idea is implausible as a general mechanism for governing contracts. Contracts are vulnerable to default when new circumstances, perceptions or information arise. Committed costs are insufficiently substantial and widespread to deal with all such eventualities, many of which are unforeseen.

Williamson rightly emphasised that most contractual disputes are resolved without direct recourse to the courts. However, this does not mean that the legal or quasi-legal institutions have no place in the everyday process of contract. As Avner Greif et al. (1994, p. 746) put it, 'the effectiveness of institutions for punishing contract violations is sometimes best judged like that of peacetime armies: by how little they must be used.' Where the rule of law prevails, the mere possibility of access to the courts is sufficient for the legal system to bear down upon contractual agreements. The threat of legal action can be silent. A very small frequency of successful litigations is required to act as a credible check on the dealings of the whole trading population.

Other authors have suggested that the state and an entire legal system can evolve spontaneously. This suggestion is bolstered by historical studies of circumstances in which contract enforcement evolved in medieval times through the efforts of trading coalitions or town guilds (Greif, 1989, 1993, 1994; Greif et al., 1994; Landa, 1994; North, 1991) or even in

\footnotetext{
2 This is not the case with regard to the later works of North (1997) who, for example, emphasises the importance of third-party or state enforcement of some laws.
} 
more modern circumstances in the absence of an adequate international political or legal authorities (Clay, 1997). These studies show that in the absence of a strong (international) legal authority, quasi-legal institutions emerged to help police and enforce contracts. The historical evidence shows that quasi-legal institutions such as trading coalitions can develop in the absence of legal and statutory ones. We can conclude that trade generally may rely on extra-legal as well as legal powers of contract enforcement. However, it would be wrong to conclude from these studies that extra-legal institutions are always adequate or efficient, or that legal authorities generally play a minor or dispensable role in all trade.

The individualist conception of law that is examined here is one that regards the law as a mere formalisation of outcomes of interactions between individuals. Many of the authors cited above do not consistently take this extreme view, for instance by accepting elsewhere that laws have significant and real effects. Nevertheless, the stated positions of Sugden and others are consistent with an individualist conception of law, and from this evidence I posit this conception as an 'ideal type'.

The individualist conception of law typically depends upon the argument that legal rules and mechanisms evolve spontaneously, without state intervention. This opens up the possibility of treating the law as an epiphenomenon of individual interactions, although some proponents of wholly spontaneous legal evolution may argue that the law is more than merely epiphenomenal. Nevertheless, by showing the limits of spontaneous legal evolution we undermine a key component of the individualist conception.

Interestingly, some of the more powerful recent criticisms of these individualist treatments of law have come from those who are in original and other respects close to the "new institutional economics'. Against Posner's (1980) theory of the emergence of property, Jack Knight (1992, p. 120) argued convincingly that relatively complex institutional rules concerning property are unlikely to emerge and be widely accepted in such circumstances: 'It is hard to see how such complicated rules could emerge from a decentralized process.'

In response to the idea of the entirely spontaneous evolution of legal structures, two types of question emerge. First, the models and historical examples used to support this idea involve the evolution of relatively simple legal rules. Would such a spontaneous evolution be possible if more complex rules were involved? Knight answered this question in the negative. Second, the models and historical examples rely on cases either (a) where a small number of traders is involved, and hence it is likely that those that renege on contracts can be recognised and punished, or (b) where traders belong to an identifiable family or ethic group and all members of this group are punished if any of its members break agreements. Would such a spontaneous evolution of legal systems be possible if there were a large number of traders, and group punishment was disallowed?

The second question has been addressed in the work of Itai Sened $(1995,1997)$. Several authors, including Greif (1993), have used game theory to illustrate these arguments. In response, Sened (1995, p. 162) observed:

Like traditional economists, most game theorists systematically overlook the role of law enforcement..... Many important social institutions do not emerge as equilibria in games among equal agents, but as equilibria in games among agents who control old institutions and agents who challenge such institutions with new demands. In particular, governments play a crucial role in the evolution of institutions that protect individual rights.

In his extended critique of the notion of property without law, Sened (1997) argued that true individual rights are established only when a territorial institution establishes its monopoly 
over the use of force. However, to accept the role of the state in the evolution of property and contract is not to romanticise this institution. Sened sees the state not as a benevolent and disinterested legislator but as an institution whose members pursue their own interests. For Sened, governments weight the benefits of granting rights against the cost of enforcement. Sened (1997, p. 123) further wrote:

Governments do not erect such structures out of benevolence or moral concern. They grant and protect rights in order to promote their own interests. But in doing so, they fulfil two crucial social functions. The function of maintaining law and order that is a necessary condition for economic growth and affluence, and the function of arbitrage between conflicting interests.

In addition, Sened showed the limitations of the aforementioned type of game theoretical model involving a few agents. With a larger number of players it is more difficult for individuals to establish mutual and reciprocal arrangements that ensure contract compliance. If trading coalitions do emerge, then these themselves take upon state-like qualities to enforce agreements and protect property. In a world of incomplete and imperfect information, high transaction costs, asymmetrically powerful relations and agents with limited insight, powerful institutions are necessary to enforce rights. These institutions result from a complex bargaining process. Sened uses an n-person prisoners' dilemma to show that the introduction of a government, enforcing rights, can often improve on a sub-optimal outcome.

It is an open question as to whether another strong institution, apart from the state, could fulfil this necessary role. However, it is not to endorse or glorify the state if we start analytically from the assumption that a state will emerge, and analyse its possible role on the process of establishment of property. It is proposed here that the emergence of a powerful institution like the state is a necessary but not a sufficient condition for the protection of property and other individual rights.

Individualist writers, from David Hume to Friedrich Hayek over-emphasised the spontaneous element in the emergence of law, as largely an outcome of individual interactions. Marxists, on the other hand, see law as an inessential epiphenomenon, which can be stripped away to reveal the 'true' a-legal, social reality beneath. Neither individualism nor Marxism is correct. In civilised societies the law is part of the essential social reality, yet at the same time it is more than the outcome of interactions between individuals. It is also an outcome of a power struggle between citizens and the state. The state benefits by maintaining its power, while citizens benefit from a regime of law and order in which they can produce and trade.

Although there are major differences between the individualist writers discussed here, there are also common features. For individualist writers, of the type discussed above, social reality consists fundamentally of individuals, individual purposes and informal relations between individuals. Legal relations are mere expressions of individual preferences and the payoffs pertaining to individual interactions. As in Marxism, the law itself plays no constitutive role in the formation of modern society.

\section{Contracts and Property Rights: The Constitutive Role of Law}

Individual property is not mere possession; it involves socially acknowledged and enforced rights. Individual property, therefore, is not a purely individual matter. It is not simply a relation between an individual and an object. It requires some kind of customary and legal apparatus of recognition, adjudication and enforcement. Such legal systems made their first 
substantial appearance within the state apparatuses of ancient civilisation. Since then the state has played a major role in the establishment, enforcement and adjudication of property rights.

At the same time, the development of any state apparatus carries the omnipresent danger that individual private property would be wilfully appropriated by the state, perhaps using the ancient norms and precedents of communal tenure. The state has the capacity to appropriate, as well as to protect and enforce, private property. For private property to be relatively secure, a particular form of state had to emerge, countered by powerful and multiple interest groups in civil society. This meant that a pluralistic state with some separation of powers, backed up by a plurality of group interests in the community at large. With such a balance of power, a framework of constitutional law could be established, in which the interests of both the state and the citizenry could be protected to some degree.

What concerns us more here is the logical and causal, rather than the historical priority of a legal apparatus over contracts and property. Some individualists uphold that contract and property are potentially spontaneous developments, not requiring a state. The valuable nugget of truth here is that these institutions always involve elements of spontaneity and social interaction, and outcomes cannot result entirely from decree. The realisation that social orders can arise without design or decree is a major insight. The particular flaw is to fail to recognise that some kind of legal or quasi-legal apparatus, however rudimentary, is necessary to preserve property rights in complex societies. The preservation of internal property rights requires sanctions against theft or fraud. Furthermore, enduring contracts rely upon systems of adjudication in the case of dispute, often using written records of precedents and rules.

To accept the role of the state in the evolution of property and contract is not to romanticise this institution. The existence of a state does not automatically give rise to private property. It is a necessary but not sufficient condition for its full development. The legal system has also to be grounded in the customs and practices of civil society. Without other checks, property is always vulnerable to state sequestration.

Clearly, trade will not develop unless there is specialisation in production and a division of labour. In addition, the rise of the state is historically and logically prior to the emergence of exchange and markets: state bureaucracies and codified legal systems are necessary preconditions for developed and enduring markets. Contrary to Williamson's (1975, p. 20) famous remark that 'in the beginning there were markets', the evolution of the market required a prior legal system. Hence we may concur with Geoffrey Ingham (1996, p. 264) that 'both historically and analytically speaking, in the beginning there were bureaucracies!'

Once contracts and property became established, regularised internal trade was possible. Markets appeared in places where a number of such exchanges could regularly take place. A market was 'a place set apart' from the traditional, ceremonial and political activities of state or society. But often the city or national state was involved in the creation, organisation and regulation of such markets (Polanyi, 1944; Polanyi et al., 1957).

This does not mean that legal systems are all that matters nor that they are always effective. In many societies, legal rules were or are ineffective. As Douglass North (1991) has pointed out, the adoption in the nineteenth century of an amended version of the US Constitution by the newly-independent South American countries did not lead to democracy. There was not an adequate civil basis for decrees of popular power. Sometimes the influences of religious and other beliefs are so strong that they negate the formal declarations of the law. In India, for instance, discrimination according to social caste has been illegal since 1948. Yet such discrimination is still widespread and is sustained by Hindu religious beliefs. The formal 
declaration of a law is not enough to make it a reality. Laws have to be rooted in the customs and observances of the people.

However, in cases where legal rules are ignored or defied, there are always other social rules that are generally being observed. Even when the law is generally observed, effective formal law can only be a representation of a subset of these underlying rules. Other social rules, not specified in law, are always important. In addition, formal legal rules are potent in societies where the rule of law prevails.

In any case, legal rules are always incomplete. Émile Durkheim (1984, p. 158) argued in 1893 that every contract itself depends on factors other than full, rational calculation: 'For in a contract not everything is contractual.' He explained that whenever a contract exists there are factors, not reducible to the intentions or agreements of individuals, which have regulatory and binding functions for the contract itself. These factors consist of rules and norms that are not necessarily codified in law. In a complex world, no complete and fully specified contract can be written. The parties to the agreement are forced to rely on institutional rules and standard patterns of behaviour, which cannot for practical reasons be established or confirmed by detailed negotiation. Typically, each person takes for granted a set of rules and norms, and assumes that the other party does the same.

Even the simplest economic activities rely on a taken-for-granted network of institutional supports. Ludwig Wittgenstein (1953) used the example of signing a cheque. Such an act depends upon the prior existence of many institutions, routines and conventions - banks, credit, and law - that are the antecedents and frameworks of socio-economic action. Without such institutions all human activity would be hopeless. Similar remarks apply to other everyday activities, such as mailing a letter or waiting for a bus. In every case, we habitually and unthinkingly depend upon a dense network of established institutions and routines. It is to these deeper and more general issues that we now turn.

\section{On Institutions in General, and Law in Particular}

At the root of the problem of the nature of legal relations is the more general issue of social ontology, concerning the nature of society, social structures and their relations with individuals. What is crucial is the ontological status of institutions in general, and property, markets and law in particular. Although in all cases they are underdeveloped, the implicit ontologies in both Marxism and the individualist writers in this respect are found wanting.

By social institutions I mean durable systems of established and embedded social rules that structure social interactions. In short, institutions are socially-embedded systems of rules. Language, money, law, systems of weights and measures, traffic conventions, table manners, firms (and other organisations) are all institutions. All institutions involve some shared conceptions, expectations and ways of thinking.

In what sense are such rules embedded? Pragmatist philosophers and 'old' institutional economists such as Thorstein Veblen (1919) argue that institutions work only because the rules involved are embedded in shared habits of thought and behaviour. The prevailing rule structure helps to create habits and preferences that are consistent with its reproduction. By reproducing shared habits of thought, institutions create strong mechanisms of conformism and normative agreement. Hence 'custom reconciles us to everything' - as Edmund Burke put it - and customary rules acquire the force of moral authority. In turn, these moral norms help to further reinforce the institution in question. Hence institutions are emergent social structures, based on commonly held habits of thought. Upon these structures, actual or 
potential patterns of social behaviour arise. Habits are the constitutive material of institutions, providing them with enhanced durability, power and normative authority.

As John Searle (1995) argued at length, the mental representation of an institution is partly constitutive of that institution since an institution can only exist if people have the necessary beliefs and mental attitudes. Accordingly, legal and other social rules are not merely formal expressions of an underlying reality but a major constitutive part of that reality. Consequently, institutions are simultaneously both objective structures 'out there', and subjective springs of human agency 'in the human head'. Institutions are in this respect like Klein Bottles: the subjective 'inside' is simultaneously the objective 'outside'.

Marxism has little to say about social rules. There is a strong emphasis on social structure; but structure is described rather vaguely in terms of relations of class and production, without further definition of those terms. Individualism sees social rules as emerging through individual interactions, while overestimating the possibilities of emergence of complex rule systems.

Two vital features are missing in both accounts. First, neither Marxism nor individualism provides an adequate picture of the institutionalised individual. Neither shows how institutions may help to reconstitute the mentality or preferences of the individuals involved. I argue elsewhere that the mechanism involved in such a reconstitution is one of institutional constraints or conventions altering habits of cognition or behaviour (Hodgson, 2002a, 2003). Second, neither Marxism nor individualism provides an adequate account of institutional change. Marxism sees institutional changes as surface expressions of other deeper - but inadequately defined - structural changes. Individualism concentrates on the spontaneous emergence of institutions from individuals but overlooks the fact that the emergence of many institutions depends on other institutions, and not all institutions can spring spontaneously from individuals alone (Hodgson, 2002c). It is specifically to the limits of spontaneous institutional emergence and self-regulation that we now turn.

\section{Self-Enforcement versus External Enforcement}

Of course, it is important to understand the significance of self-organising institutions and spontaneous orders. A focus on self-organising aspects of the social system can be traced back to David Hume and Adam Smith, and it is a major theme in the Austrian school of economics from Carl Menger to Friedrich Hayek. The literature on self-organisation and spontaneous orders provides the essential insight that institutions and other social phenomena can arise in an undesigned way through structured interactions between agents.

However, this does not mean that the concepts of self-organisation or spontaneous order are sufficient for an understanding of all institutions. They do not tell us the whole story. Indeed, it can be argued that much of the literature on institutions is disfigured by a relatively excessive emphasis on these (albeit essential) ideas, to the detriment of other vital issues. These issues are briefly introduced here.

It is important not to overlook the fact that different institutions depend on different types of rule, incentive structure, preference stability or normative salience. The first relevant distinction is between coordination-type setup and other types of incentive structure. Other issues, such as moral pressure and changes in preference functions, will be considered later. At first we assume individuals with given preference functions. 
Coordination rules typically provide incentives for everyone to conform to the convention. For this reason, a coordination outcome can be relatively stable and self-policing. Language is an example. Willard van Orman Quine (1960) made the point that language has an errorcorrecting regime. Individuals have an incentive to make their words clear. As an essential condition of communication, the coding itself (the signifier) must be unmistakable, even if the meaning (the signified) remains partly ambiguous. In communication we have strong incentives and inclinations to use words and sounds in a way that conforms as closely as possible to the perceived norm. Although languages do change through time, there are incentives to conform to, and thus reinforce, the linguistic norms in the given region or context. Norms of language and pronunciation are thus largely self-policing.

Similarly, some (but not all) legal rules have a strong self-policing element. For example, there are obvious incentives to stop at red traffic lights and to drive on the same side of the road as others. Although infringements will occur, these particular laws can be partly enforced by motorists themselves, because infringements can increase perceived personal risks. But even here some variations are possible. Motorists in a 'macho' culture may relish taking such risks. The possibility of self-policing institutions depends on perceived payoffs, and such perceptions can sometimes be moulded by cultural circumstances. This important issue is raised again later below; prior to that point we continue to assume exogenously given preference functions.

A coordination outcome can be self-enforcing; because not only does each player lack any incentive to change strategy, but also each player wishes that other players keep to their strategy as well (Schotter, 1981, pp. 22-3). If agents have compatible preferences and strategies in this sense, then coordination rules can often emerge spontaneously and be selfregulating. For example, if the rule 'drive on the right-hand-side' of the road emerges, then each driver has an incentive to stick to this rule and also wishes that other drivers would do likewise. Even if I prefer to drive on the left, but I find myself in a country where driving on the right is the convention, then I will drive on the right, and others will prefer that I do this. I do this because my second-best option is itself much better than a head-on collision! A coordination outcome has characteristics of stability and self-enforcement, even when the outcome is not ideal for everyone involved. An example of this is illustrated in figure 1.

Player 2

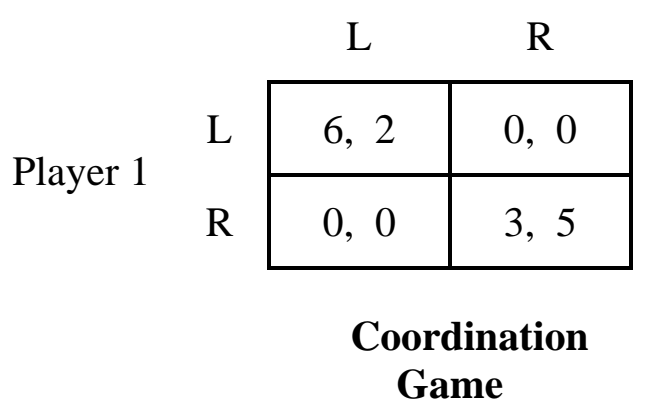

Player 2

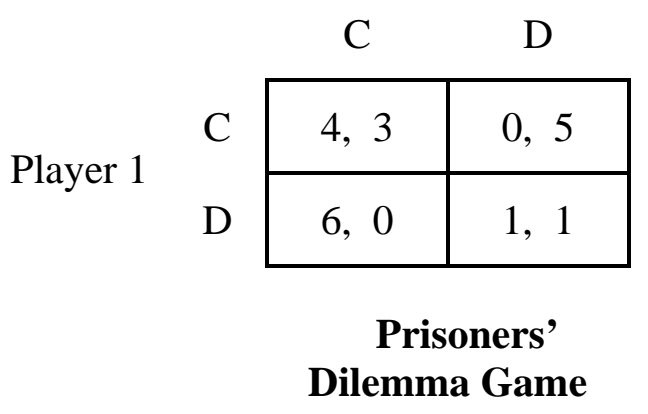

Figure 1: A Coordination Game and a Prisoners’ Dilemma Game

As an example of a contrasting case, consider the famous Prisoners' Dilemma game, as also illustrated in figure 1 . At least in a one-shot play of this game, each player has an incentive to 
defect. The situation of mutual cooperation (C-C) is not a Nash equilibrium because each player can gain an advantage by shifting from (C) cooperation to (D) defection. The Nash equilibrium is (D-D), where each player gets less than she would if both players cooperated (C-C). A 'spontaneous order' may emerge but it is clearly sub-optimal, by any reasonable criterion. Although a Nash equilibrium may emerge, its social and individual suboptimality always brings it into question.

Robert Axelrod (1984) has famously argued that with repeated (indefinite or infinite) plays of the Prisoners' Dilemma game, enduring cooperation (C-C) can emerge because each player can learn to reciprocate attempts to cooperate by the other, and punish defection when it occurs by further defection. But this result is not universal and Axelrod's 'tit-for-tat' strategy can be out-competed by alternative behavioural rules (Binmore, 1998). There is no guarantee that cooperation will emerge or be enduring even in repeated games of this type.

Compare some of the key differences between a coordination game and a Prisoners' Dilemma game. In the case of a coordination game the incentives to conform to the emergent convention are strong and enduring, even if it is not everyone's first choice. Furthermore, as in the representative cases of languages and rules of the road, normative issues are often secondary to the straightforward incentives and disincentives involved. This partly because the incentive structure involved is normally sufficient to reach an enduring and acceptable outcome. In a Prisoners' Dilemma game there is also a Nash equilibrium. The equilibrium is stable in the one-shot case, but it will not necessarily endure if the game is repeated. Furthermore, the transparent sub-optimality of the Nash equilibrium, from both the individual and the social point of view, by Paretian and other plausible criteria, raises normative questions including the desirability of third-party intervention to improve the situation for everyone involved. We make a big mistake of we treat these two types of situation as the same, or if we concentrate on models of self-organisation based on coordination-type incentive structures, while neglecting other equally important incentive configurations.

With its potential for sub-optimal outcomes, a Prisoners' Dilemma situation would be a candidate for intervention by a third party such as the state. It is conceivable that such a third party could intervene to deter or prevent defection. For example, if the state made defection illegal and subject to a fine of 3 units (or alternatively taxed defection by 3 units), then the Prisoners' Dilemma game in Figure 1 would be transformed to the different type of game in Figure 2. Clearly, this is no longer a Prisoner's Dilemma game: both players have an incentive to cooperate. ${ }^{3}$

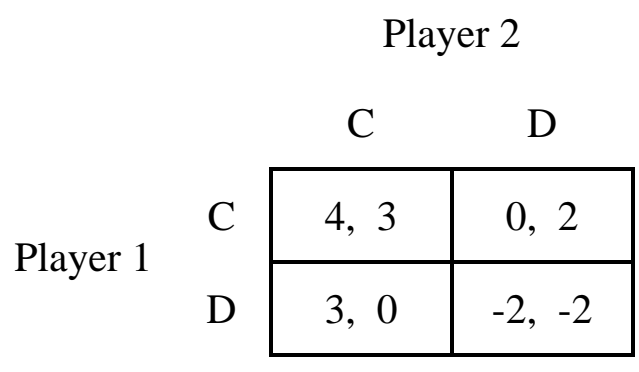

Figure 2: The Previous Prisoners’ Dilemma Game Transformed

\footnotetext{
3 See Ostrom et al. (1994, p. 77) for a discussion of the way in which additional rules such as these may 'affect the benefits and costs assigned to actions and outcomes'.
} 
Note also that a similar structure of payoff incentives may be attainable by an alteration in the preferences of the players, as well as by a tax or a fine. If a view prevailed that defection was intrinsically bad or immoral, then agents might internalise such ideas in their own preferences. If these changes in preferences were strong enough, they could lead to changes in perceived payoffs similar to those represented in Figure 2, and mutual cooperation would result. Arguably, such changes in preferences could result from a period of mutual cooperation in repeated plays of the game. Without propaganda or coercion, individuals might become freely persuaded that cooperation has a greater relative moral superiority over defection. This would be a case of systemically endogenous enforcement, rather than enforcement from outside. Alternatively, or in addition, a powerful third party could help by example, persuasion or propaganda to shift individual preferences. For example, a democratic state might implore us to fasten seat belts in cars or recycle our garbage, or a totalitarian regime could adopt more sinister methods of propaganda or coercion to reach similar goals.

Of course, such a practical transformation of incentives and outcomes would be very difficult to engineer in complex, real world circumstances. But this does not mean that state intervention is always dysfunctional. The transformation in Figure 2 dramatically oversimplifies the real world complexities and problems of knowledge involved. But it does show that payoff manipulations can have important qualitative effects. The practical possibility of efficacious state intervention is a matter for detailed theoretical and empirical enquiry in specific circumstances.

A key point here is that while self-organisation and spontaneous orders are important and widespread in both nature and society, they rely on specific types of incentive alignment that ensure that most individuals have no reason to deviate from or disrupt the emergent order. Other payoff structures may not lead to optimal or satisfactory outcomes and additional factors may be necessary to reach a satisfactory outcome. One possibility is to rely on the enforcement measures of a third party. Another possibility is that the persistence of a satisfactory solution for a while may lead to a shift of preferences that favours its prolongation. These two possibilities are not mutually exclusive and one process could benefit from the other. The first process involves external enforcement and the second would be an example of systemically endogenous enforcement through reconstitutive downward causation of individual preferences (Hodgson, 2002a, 2003).

Normative issues are clearly raised at this point. Although all rules involve costs and benefits, there is a big difference between following a rule because it is convenient to do so, and following a rule because of a normative belief. Coordination rules are foremost examples of rules that are followed primarily because of convenience. Viktor Vanberg (1994, p. 65) has rightly pointed out that writers in the spontaneous order tradition - from Hume and Smith through Menger to Hayek - have failed to account adequately for the difference between coordination rules and rules involving normative constraints (legal or moral rules). Walter Schultz (2001, pp. 64-6) stressed a similar distinction in his powerful discussion of the problem of enforcement of social rules.

Until recently, as noted above, the problem of enforcement has been neglected in much of the 'new' institutionalist tradition. Some institutions are largely self-enforcing. But things are even more different with many other laws and institutions. Laws that restrict behaviour, where there are substantial, perceived net advantages to transgression, are the ones that require the most policing. Hence people frequently evade tax payments or break speed limits. Without 
some policing activity the law itself is likely to be infringed, debased and 'brought into disrepute.’

Accordingly, there are incentives to debase money. With potential quality variation, individual agents have an obvious incentive to use a less costly, poor quality or fake version of the medium of exchange. Given that traders cannot readily detect all variations, then forgeries and debasements are possible. If they are allowed to endure, then bad money will drive out the good. Money is not self-policing in the same way as language. ${ }^{4}$

Self-policing mechanisms can be undermined if there is the possibility of undetected variation from the norm and there is sufficient incentive to exert such variations. Language and money differ in this respect. The argument for enforcement by a third party such as the state is thus stronger in the case of money and some laws, than in the case of language.

Furthermore, the boundary between potentially self-policing and other institutional arrangements depends on perception, which in turn may depend on the cultural context. While self-organisation is an extremely important phenomenon in both nature and human society, it cannot account for all the peculiar features of human social organisation. To treat human society as closely analogous to the spontaneous emergence of order in a simple chemical system or a slime-mould is to belittle the reality of human agency. It would ignore the importance of reconstitutive downward causation on human agents, including the human capacities to prefigure, imitate and adopt the dispositions of their neighbours.

\section{Some Conclusions and Implications}

We are now in a position to draw the key threads of the argument together. Marxism belittles the role and place of law in modern society by treating it as an epiphenomenon of unspecified, underlying social relations. Individualism sees law as an expression of interactions between individuals. Its account of the emergence of institutions exaggerates the relative importance of coordination games, to the neglect of situations where legal rules do not emerge so readily through individual interactions.

To overcome these problems, two key propositions must be accepted. First, at least in a society subject to the rule of law, legal relations are an important part of 'underlying' social reality and not merely epiphenomenal. This does not mean that social reality is or can be entirely defined in legal terms, because legal rules are inevitably incomplete. But it does mean that law is part of the constitution and nature of social reality, and it governs specific human interactions such as commodity exchanges and contract enforcements. As Warren Samuels (1989, p. 1567) put it in an article reaching a similar conclusion: 'the law is a function of the economy, and the economy (especially its structure) is a function of law.'

Second, many important legal rules, enforcements and structures cannot emerge spontaneously through individual interactions. They require additional third party enforcement by the state or another strong institution. This means that many key institutions and legal relations, arguably including property and markets, exist as a result of a combination of spontaneous and statutory mechanisms. The existence of one institution has to be considered in relation to the others that help to support and sustain it. Institutions are generally and inevitably intertwined, and often provide essential mutual support for one another.

\footnotetext{
${ }^{4}$ See my discussion of Menger's theory of money in Hodgson (2001, ch. 7).
} 
At least in countries where the rule of law prevails, laws are part of socio-economic reality and have real effects. In general, legal relations are not mere formalities, but are backed with the powers and sanctions of the state legal system. Laws set bounds on our behaviour, including the kind of contracts that may be concluded. The courts and police, even if they are used infrequently, can be used to enforce the fulfilment of contracts or to enforce the collection of damages for non-performance. These are clearly matters of power and control. Legal relations do not constitute the whole story, but they are nevertheless vital. The nature of legal relations is an important determining factor for socio-economic behaviour and outcomes.

The propositions in the preceding two paragraphs are explicit or implicit in writings of some 'old' institutional economists (Commons, 1924; Mitchell, 1937). In addition, however, similar views are expressed, with criticisms of some of the defects of the individualist account, by a number of authors working at least nominally within the tradition of the 'new' institutionalism (Knight, 1992; North, 1997; Sened, 1995, 1997). Perhaps their fullest development so far is in modern 'economic sociology' (Friedland and Sanders, 1985; Block, 1990; Campbell and Lindberg, 1990; Lie, 1997).

The argument here reinforces Karl Polanyi's (1944) view that a self-regulating market is unattainable and his conclusion that markets are inevitably intertwined with the state. But the argument here is different in some respects. Polanyi argued that the state had to intervene in the development of a market economy to avoid malfunctions and excesses. Polanyi (1944, p. 76) wrote: 'Administrators had to be constantly on the watch to ensure the free workings of the system. ... Society protected itself against the perils inherent in a self-regulating market system'. The argument here does not negate these propositions but combines them with the additional and reinforcing insight that markets and exchange are in part constituted by legal relations and the state. The state is involved in the market not merely to ensure its functioning and restrain any potential havoc, but also to constitute its very existence. This underlines the enduring relevance and importance of Polanyi's writings for the understanding of the complex relationship between the market and the state, even the arguments present here are not identical to Polanyi’s in every respect. 


\section{References}

Alchian, Armen A. (1977) 'Some Implications of Recognition of Property Right Transaction Costs’, in Brunner, Karl (ed.) (1977) Economics and Social Institutions: Insights from the Conferences on Analysis and Ideology (Boston, MA: Martinus Nijhoff), pp. 234-55.

Axelrod, Robert M. (1984) The Evolution of Cooperation (New York: Basic Books).

Binmore, Kenneth (1998) Review of Complexity and Cooperation by Robert Axelrod, Journal of Artificial Societies and Social Situations, 1(1).

$<$ http://jasss.soc.surrey.ac.uk/JASSS/1/1/review1.html>

Block, Frederick (1990) Postindustrial Possibilities: A Critique of Economic Discourse (Berkeley: University of California Press).

Campbell, John L. and Lindberg, Leon N. (1990) 'Property Rights and the Organization of Economic Activity by the State', American Sociological Review, 55(5), October, pp. 63447.

Clay, Karen (1997) 'Trade Without Law: Private-Order Institutions in Mexican California', Journal of Law, Economics and Organization, 13(1), April, pp. 202-31.

Commons, John R. (1924) Legal Foundations of Capitalism (New York: Macmillan).

Durkheim, Émile (1984) The Division of Labour in Society, translated from the French edition of 1893 by W. D. Halls with an introduction by Lewis Coser (London: Macmillan).

Friedland, Roger and Sanders, Jimy (1985) 'The Public Economy and Economic Growth in Western Market Economies’, American Sociological Review, 50(4), August, pp. 421-37.

Greif, Avner (1989) 'Reputations and Coalitions in Medieval Trade: Evidence on the Maghribi Traders’, The Journal of Economic History, 49(4), December, pp. 857-82.

Greif, Avner (1993) 'Contract Enforceability and Economic Institutions in Early Trade: The Maghribi Traders’ Coalition', American Economic Review, 83(3), June, pp. 525-48.

Greif, Avner (1994) 'On the Political Foundations of the Late Medieval Commercial Revolution: Genoa During the Twelfth and Thirteenth Centuries', Journal of Economic History, 54(2), June, pp. 271-87.

Greif, Avner, Milgrom, Paul and Weingast, Barry R. (1994) 'Coordination, Commitment, and Enforcement: The Case of the Merchant Guild', Journal of Political Economy, 102(4), August, pp. 745-76. Reprinted in Knight, Jack and Sened, Itai (eds) (1995) Explaining Social Institutions (Ann Arbor, MI: University of Michigan Press), pp. 27-57.

Heijdra, Ben J., Lowenburg, Anton D. and Robert J. Mallick (1988) 'Marxism, Methodological Individualism, and the New Institutional Economics', Journal of Institutional and Theoretical Economics, 144(2), pp. 296-317.

Hodgson, Geoffrey M. (1984) The Democratic Economy: A New Look at Planning, Markets and Power (Harmondsworth: Penguin).

Hodgson, Geoffrey M. (1999) Economics and Utopia: Why the Learning Economy is Not the End of History (London and New York: Routledge).

Hodgson, Geoffrey M. (2001) How Economics Forgot History: The Problem of Historical Specificity in Social Science (London and New York: Routledge). 
Hodgson, Geoffrey M. (2002a) 'Reconstitutive Downward Causation: Social Structure and the Development of Individual Agency' in Fullbrook, Edward (ed.) (2002) Intersubjectivity in Economics: Agents and Structures (London and New York: Routledge), pp. 159-80.

Hodgson, Geoffrey M. (2002b) 'The Legal Nature of the Firm and the Myth of the FirmMarket Hybrid', International Journal of the Economics of Business, 9(1), February, pp. 37-60.

Hodgson, Geoffrey M. (2002c) 'The Evolution of Institutions: An Agenda for Future Theoretical Research', Constitutional Political Economy, 13(2), June, pp. 111-27.

Hodgson, Geoffrey M. (2003) 'The Hidden Persuaders: Institutions and Individuals in Economic Theory', Cambridge Journal of Economics, 27(2), March, pp. 159-75.

Hodgson, Geoffrey M. (2004) The Evolution of Institutional Economics: Agency, Structure and Darwinism in American Institutionalism (London and New York: Routledge) forthcoming.

Ingham, Geoffrey (1996) 'Money is a Social Relation', Review of Social Economy, 54(4), Winter, pp. 507-29.

Knight, Jack (1992) Institutions and Social Conflict (Cambridge: Cambridge University Press).

Landa, Janet (1994) Trust, Ethnicity, and Identity: Beyond the New Institutional Economics of Ethnic Trading Networks, Contract Law, and Gift Exchange (Ann Arbor, MI: University of Michigan Press).

Lie, John (1997) 'Sociology of Markets’, Annual Review of Sociology, 23, pp. 341-60.

Marx, Karl (1971) A Contribution to the Critique of Political Economy, translated from the German edition of 1859 by S. W. Ryazanskaya and edited with an introduction by Maurice Dobb (London: Lawrence and Wishart).

Marx, Karl (1976) Capital, vol. 1, translated by Ben Fowkes from the fourth German edition of 1890 (Harmondsworth: Pelican).

Marx, Karl and Engels, Frederick (1976) Karl Marx and Frederick Engels, Collected Works, Vol. 5, Marx and Engels: 1845-47 (London: Lawrence and Wishart).

Mises, Ludwig von (1949) Human Action: A Treatise on Economics (London: William Hodge).

Mitchell, Wesley C. (1937) The Backward Art of Spending Money and Other Essays (New York: McGraw-Hill).

North, Douglass C. (1991) 'Institutions', Journal of Economic Perspectives, 5(1), Winter, pp. 97-112.

North, Douglass C. (1997) 'Prologue’ in Drobak, John N. and Nye, John V. C. (eds) (1997) The Frontiers of the New Institutional Economics (San Diego and London: Academic Press), pp. 3-28.

Ostrom, Elinor, Gardner, Roy and Walker, James (1994) Rules, Games, and Common-Pool Resources (Ann Arbor, MI: University of Michigan Press).

Polanyi, Karl (1944) The Great Transformation: The Political and Economic Origins of Our Time (New York: Rinehart). 
Polanyi, Karl, Arensberg, Conrad M. and Pearson, Harry W. (eds) (1957) Trade and Market in the Early Empires (Chicago: Henry Regnery).

Posner, Richard A. (1980) 'A Theory of Primitive Society, With Special Reference to Law', Journal of Law and Economics, 23(1), pp. 1-53.

Quine, Willard van Orman (1960) Word and Object (Cambridge, MA: Harvard University Press).

Samuels, Warren J. (1989) 'The Legal-Economic Nexus', George Washington Law Review, 57(6), August, pp. 1556-78.

Schotter, Andrew R. (1981) The Economic Theory of Social Institutions (Cambridge: Cambridge University Press).

Schultz, Walter J. (2001) The Moral Conditions of Economic Efficiency (Cambridge and New York: Cambridge University Press).

Searle, John R. (1995) The Construction of Social Reality (London: Allen Lane).

Sened, Itai (1995) 'The Emergence of Individual Rights', in Knight, Jack and Sened, Itai (eds) (1995) Explaining Social Institutions (Ann Arbor, MI: University of Michigan Press), pp. 161-88.

Sened, Itai (1997) The Political Institution of Private Property (Cambridge: Cambridge University Press).

Sensat, Julius (1988) 'Methodological Individualism and Marxism', Economics and Philosophy, 4, pp. 189-219.

Sugden, Robert (1986) The Economics of Rights, Co-operation and Welfare (Oxford: Basil Blackwell).

Vanberg, Viktor J. (1994) Rules and Choice in Economics (London: Routledge).

Veblen, Thorstein B. (1919) The Place of Science in Modern Civilization and Other Essays (New York: Huebsch).

Williamson, Oliver E. (1975) Markets and Hierarchies: Analysis and Anti-Trust Implications: A Study in the Economics of Internal Organization (New York: Free Press).

Williamson, Oliver E. (1983) 'Credible Commitments: Using Hostages to Support Exchange’, American Economic Review, 74(3), September, pp. 519-40.

Wittgenstein, Ludwig (1953) Philosophical Investigations (Oxford: Basil Blackwell). 